\title{
Are antiangiogenics a good 'partner' for immunotherapy in ovarian cancer?
}

\author{
Elena García-Martínez ${ }^{1} \cdot$ Andres Redondo $^{2}$ (i) $\cdot$ Josep Maria Piulats ${ }^{3}$ (i) $\cdot$ Analía Rodríguez $^{4} \cdot$ Antonio Casado $^{5}$
}

Received: 31 January 2020 / Accepted: 6 July 2020 / Published online: 20 July 2020

(c) The Author(s) 2020

\begin{abstract}
Ovarian cancer (OC) is associated with poor survival because there are a limited number of effective therapies. Two processes key to OC progression, angiogenesis and immune evasion, act synergistically to promote tumor progression. Tumorassociated angiogenesis promotes immune evasion, and tumor-related immune responses in the peritoneal cavity and tumor microenvironment (TME) affect neovascular formation. Therefore, suppressing the angiogenic pathways could facilitate the arrival of immune effector cells and reduce the presence of myeloid cells involved in immune suppression. To date, clinical studies have shown significant benefits with antiangiogenic therapy as first-line therapy in OC, as well as in recurrent disease, and the vascular endothelial growth factor (VEGF) inhibitor bevacizumab is now an established therapy. Clinical data with immunomodulators in OC are more limited, but suggest that they could benefit some patients with recurrent disease. The preliminary results of two phase III trials have shown that the addition of immunomodulators to chemotherapy does not improve progression-free survival. For this reason, it could be interesting to look for synergistic effects between immunomodulators and other active drugs in OC. Since bevacizumab is approved for use in OC, and is tolerable when used in combination with immunotherapy in other indications, a number of clinical studies are underway to investigate the use of bevacizumab in combination with immunotherapeutic agents in OC. This strategy seeks to normalize the TME via the anti-VEGF actions of bevacizumab, while simultaneously stimulating the immune response via the immunotherapy. Results of these studies are awaited with interest.
\end{abstract}

Keywords Ovarian cancer $\cdot$ Angiogenesis $\cdot$ Immune evasion $\cdot$ Immunomodulator $\cdot$ Bevacizumab

\section{Introduction}

According to 2018 estimates, approximately 300,000 women around the world are diagnosed with ovarian cancer (OC) each year and approximately 185,000 women die from OC $[1,2]$. Despite the fact that most patients respond to initial

Elena García-Martínez

helenagarciam@gmail.com

1 Medical Oncology Department, Hospital Universitario Morales Meseguer, IMIB, Avenida Marques de los Velez, 30008 Murcia, Spain

2 Medical Oncology Department, Hospital Universitario La Paz-IdiPAZ, Madrid, Spain

3 Institut Català d'OncologiaMedical Oncology Unit IDIBELL/OncoBell - CIBERONC, Barcelona, Spain

4 Roche Farma S.A., Madrid, Spain

5 Department of Medical Oncology, Hospital Clínico San Carlos, Madrid, Spain chemotherapy and a few can obtain cure with surgery and first-line chemotherapy, the vast majority of patients with advanced disease will relapse within 2 years after diagnosis. The standard first-line chemotherapy includes at least a platinum and taxane combination [3], usually carboplatin and paclitaxel.

Epithelial OC cannot be considered as a single entity as it encompasses several neoplasms, each with specific clinical pathological characteristics [4]. Specific genomic patterns provide an opportunity for targeted therapy, such as inhibitors of poly ADP ribose polymerase (PARP) in patients with BRCA1/2 mutations [5], mainly high-grade serous carcinoma, or Ras/Raf/MEK/ERK inhibitors in patients with lowgrade serous carcinoma or mucinous ovarian carcinoma [4].

The role played by angiogenesis in the tumor microenvironment (TME), favoring the growth and spread of the tumor is well established [6]. In addition, important advances have been made in the understanding of the "immunity-cancer" cycle, identifying ways in which the tumor escapes immune 
surveillance, thereby allowing the tumor to grow and metastasize [7]. The "immunity-cancer" relationship is determined by a complex interplay of the intrinsic properties of the tumor (including genetics), host genetics, and environmental factors [7]. OC TME is highly immunosuppressive shielding the tumor from the body's protective immune cells, and allowing unsuppressed progression [8].

Advances in our understanding of cancer biology have led to the development of angiogenesis inhibitors and immunotherapies as cancer treatments. While the angiogenesis inhibitor bevacizumab is now a common systemic therapy for OC, no immunotherapy has yet been approved for this indication. However, there are currently many clinical trials that are evaluating different immune checkpoint inhibitors in $\mathrm{OC}$, some of them with bevacizumab.

The aim of this review is to analyze the possible interaction between angiogenesis and immunomodulation mechanisms specifically in OC and describe the rationale for combining antiangiogenesis agents with immunotherapy based on synergy and complementary mechanisms of action.

\section{Importance of tumoral angiogenesis in ovarian cancer}

Tumor growth and progression rely greatly on the presence of blood vessels to provide oxygen and nutrients and to remove waste products [9]. In physiological conditions angiogenesis is activated by proangiogenic factors, including vascular endothelial growth factor (VEGF), fibroblast growth factor (FGF), transforming growth factor (TGF) $-\beta$, epidermal growth factor and angiopoietin, and regulated by the interplay of these proangiogenic factors with antiangiogenic factors [10, 11, 12, 13].

Tumors have an aberrant vasculature that impairs the delivery of oxygen and nutrients to the tumor, resulting in hypoxia and a low intra-tumoral $\mathrm{pH}[9,14]$. This environment favors selection of more malignant tumor cell clones and the release of more proangiogenic growth factors, generating a vicious cycle of impaired blood vessel formation and poor perfusion [14]. This cycle is mediated in part by the activation of hypoxia-inducible factors (HIFs) that maintain oxygen homoeostasis by stimulating vasodilation and stimulating angiogenesis [15]. Additionally, HIF signaling improves the metabolic fitness of tumor cells so that they preferentially take up nutrients, starving healthy stromal cells in their vicinity [16].

VEGF is the most studied angiogenesis mediator [6], and its receptor is expressed frequently on OC cells [17]. VEGF promotes proliferation, survival and migration of endothelial cells (ECs) and is essential for blood vessel formation [14]. Increased VEGF expression in OC is a marker of cancer stage and grade [18], tumor progression [17] and lower survival rates [4].

Ascites is common in women with advanced OC [19], and the ascites fluid is rich in proangiogenic factors including VEGF and immunosuppressive cells [20,21]. The concentration of proangiogenic factors in ascites is a marker of OC tumor invasiveness and a prognostic indicator of worse outcome in OC $[20,22,23]$.

\section{Importance of the immune system in ovarian cancer}

OC has a unique relationship with the immune system, which can be partially attributed to its site in the peritoneal cavity, as well as the characteristics of the TME.

The peritoneal environment supports the dissemination of OC cells, via the omental vasculature and the peritoneal fluid itself. Even in the early stages of OC, when the tumor is confined to the ovary, cancer cells are detectable in peritoneal lavage fluid [24]. Peritoneal fluid is awash with a range of immune-related cells, including $\mathrm{T}$ cells and tumor-associated macrophages (TAMs), which contribute to tumor cell proliferation and immune evasion [25].

In addition, 'milky spots' on the omentum are clusters of leukocytes similar to follicles of secondary lymphoid tissue that collect antigens and pathogens from the peritoneal cavity and promote an immune response. When OC cells colonize the omentum, the milky spots initially proliferate and grow, primarily driven by macrophage recruitment. However, despite this initial protective response, tumor cells generally grow unchecked in the omentum, presumably because the OC cells are able to suppress the local immune reaction or evade detection [26].

Similar immune evasion processes appear to be at play within the primary ovarian tumor, where the TME modulates tumor cell-induced immunosuppression. TAMs, myeloid-derived suppressor cells (MDSC) and regulatory $\mathrm{T}$ cells (Treg) are considered crucial for the maintenance of an immunosuppressive TME [24]. TAMs are similar in structure and function to normal peritoneal macrophages but they show upregulated levels of genes controlling extracellular matrix remodeling. So they might promote cancer progression by adjusting the matrix of the TME and facilitating the invasion of cancer cells into surrounding tissues [25]. These TAMs are M2 polarized, express CD163 surface marker and are activated by IL-13 and IL-4 [27]. Tregs produce immunosuppressive chemokines such as IL-10 and TGF- $\beta$, and express membrane-associated receptors involved in immune evasion, such as cytotoxic T-lymphocyte antigen 4 (CTLA-4) [28].

Other tumor-infiltrating lymphocyte (TILs) that may be present in the TME include CD4 + T-helper cells and 
CD8 + cytotoxic T-lymphocytes. CD8 + cells would normally have antitumor activity, but these effects are suppressed by the upregulation of immune checkpoint molecules. Within the TME, T-cell receptor sensitization and interferon (IFN)- $\gamma$ secretion make the tumor cell and the antigen-presenting cell express the programmed cell death-1 (PD-1) receptor and its ligand (PD-L1) on their surfaces. Along with increased PD-1 expression, the upregulation of the lymphocyte activation gene 3 (LAG3) negatively affects the function of the CD8 + lymphocytes, greatly diminishing their cytotoxic activity against the tumor [24]. It should be noted that lymphocyte infiltration is histotype-specific [29]. CD 8 + TILs were observed in $\sim 50 \%$ of patients with mucinous or clear cell histologies but were more common in high-grade serous (in $~ 83 \%$ of patients), low-grade serous $(\sim 73 \%)$, and endometrioid $(\sim 72 \%)$ histotypes [29].

The expanding knowledge based on the TME in OC has led to research into potential biomarkers of response to different therapies. However, the TME has proven to be heterogeneous between the primary ovarian tumor and individual metastases [30], and this intra- and inter-tumor heterogeneity presents a challenge for interpreting the clinical significance of different biomarkers in biopsy samples [31].

The importance of TILs as a favorable prognostic biomarker in OC seems unquestionable since the publication of seminal research by Zhang and colleagues in 2003 [32]. The prognostic value of CD8 + TILs is independent of residual disease following surgical cytoreduction [29]. These cells have proven their prognostic significance in a range of $\mathrm{OC}$ types including high-grade serous, endometrioid, and mucinous subtypes, but not in patients with low-grade serous or clear cell cancer [29].

Data are contradictory regarding the prognostic value of PD-L1 in patients with OC; there are studies relating PD-L1 expression with a favorable prognosis [33, 34, 35] and with a poor prognosis $[34,36]$. This discrepancy is probably due to the absence of an agreed system of immunohistochemical assessment, different cut points, different types of antibodies, and differential expression in PD-L1 between cells types, such as stroma cells, epithelium, and macrophages [33, 37].

Mutational load has been used as a biomarker for response to anti-PD-1/PD-L1 treatment in some types of solid tumors [38]. It is most likely that the greater load of tumor-specific neoantigens in the most mutated lesions favors the recruitment of a greater number of TILs [39]. Since the mutational load in OC is lower than in many other types of solid tumor (Fig. 1) [40], the usefulness of this biomarker may be limited in the ovarian setting; however, mutational quality may be of more value since certain mutations confer a greater effect on lymphocyte recruitment than others.

\section{Biological rationale for the antiangiogenic-immunotherapy combination in cancer}

Within the TME, tumor angiogenesis and immune suppression play interconnected roles in promoting tumor progression and metastasis [41].

The cytokines and angiogenic factors released by TME cells, such as VEGF, TGF $\beta$ and prostaglandin $\mathrm{E}_{2}\left(\mathrm{PGE}_{2}\right)$, mediate immunosuppression by reducing antigen presentation to $\mathrm{T}$ cells and the effector response of T cells [9]. VEGF in particular modulates immunosuppression by directly and indirectly affecting the function of cells responsible for innate and adaptive immunity (Fig. 2) [9, 42, 43]. The direct mechanisms include an increased recruitment of Treg cells, inflammatory monocytes. and TAMs that are reprogrammed from the M1 subtype of 'classically activated' macrophages with anticancer activity to a pro-tumoral M2 phenotype; DC maturation inhibition, which affects the presentation of antigens and the activation of cytotoxic CD8+cells; and the proliferation of atypical ECs with immunosuppressor phenotype $[9,42,43]$.
Fig. 1 Mutational load in different types of solid tumors [40]. $M M R d$ mismatch repair-deficient; $M M R p$ mismatch repairproficient; no number; NSCLC non-small-cell lung cancer

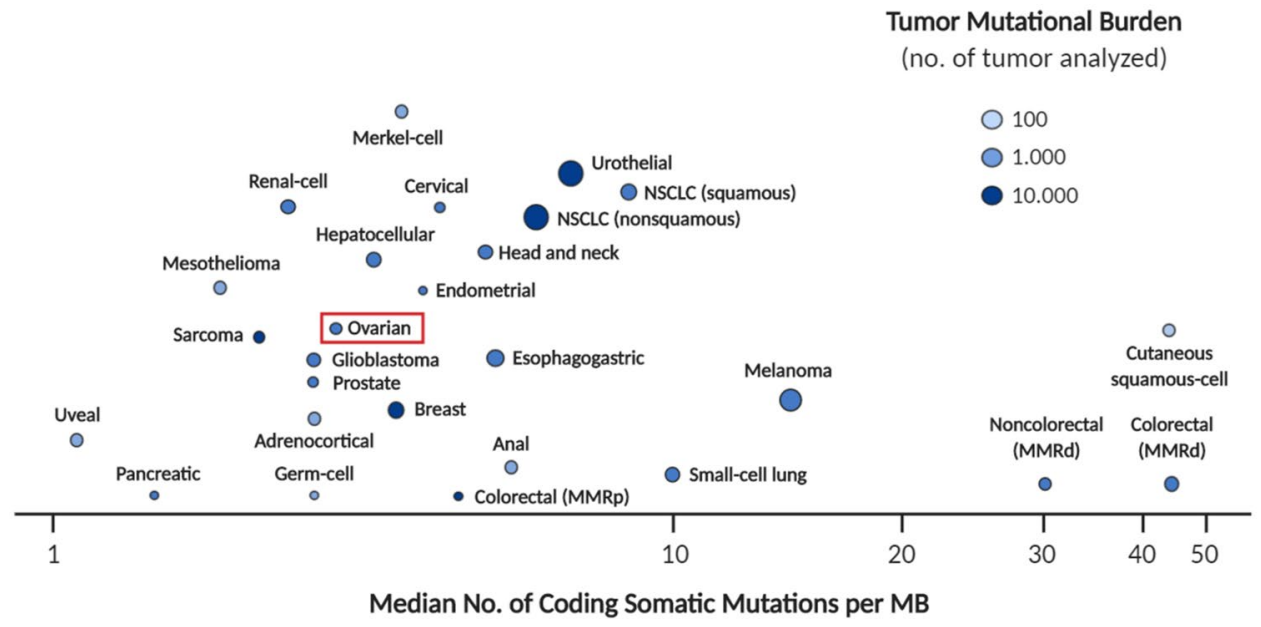


Fig. 2 The effect of tumor angiogenic factors on immune cells and the vascular endothelium [42]. Modified from Khan and Kerbel, 2018. ANG2 angiopoietin 2; $H G F$ hepatocyte growth factor; $I L-10$ interleukin 10 ; $P D-L 1$ programmed deathligand $1 ; P D G F A B$ plateletderived growth factors; Treg regulatory T cell; VEGF vascular endothelial growth factor

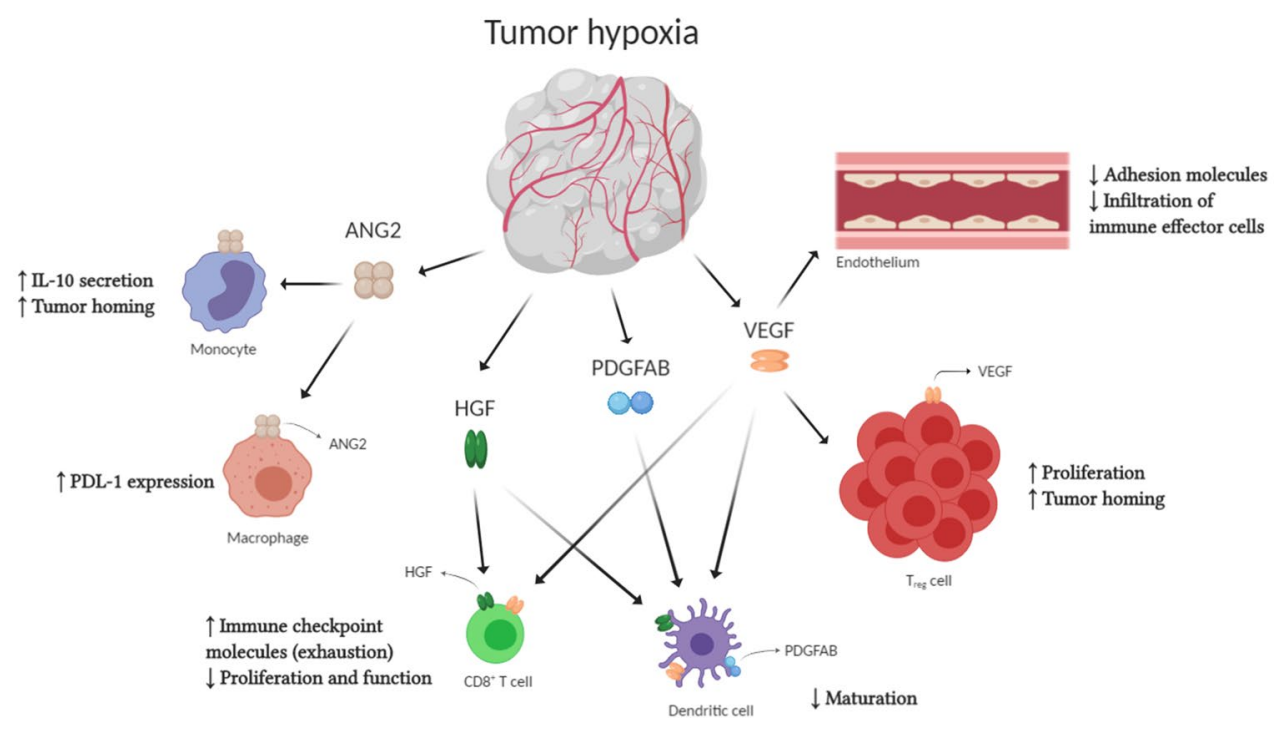

Other angiogenic molecules are also involved in these processes. For example, angiopoietin 2 (ANG2) induces immunosuppression by binding to macrophages, where it upregulates PD-L1 [42]. Hepatocyte growth factors (HGF) and platelet derivatives (PDGFAB), bind to DCs, thus suppressing their maturation.

VEGF also indirectly affects the inflammatory response by inducing "endothelial anergy," whereby the endothelium has a dysfunctional response to inflammatory signals [44]. Normally, inflammatory mediators upregulate adhesion molecules, thereby trafficking immune cells from the blood to sites of inflammation. However, in tumors, VEGF and other angiogenic factors downregulate the expression of different adhesion molecules, such as intercellular adhesion molecule 1 (ICAM1) and vascular cell adhesion molecule 1 (VCAM1). This reduces the trafficking of natural killer (NK) cells to the tumor. VEGF also inhibits the secretion of chemokines such as CXC-chemokine ligands 10 and 11, which would normally attract $\mathrm{T}$ cells to the endothelium [42]. Additionally, the altered expression of adhesion molecules facilitates the infiltration of immunosuppressive cells (such as Tregs) into tumoral tissue [44].

Further indirect effects of VEGF in the endothelium include the production FAS antigen ligand (FASL) by the tumor-related blood vessels. This ligand acts as a barrier to $\mathrm{CD} 8+\mathrm{T}$-cell infiltration by causing apoptosis of these cells, but without affecting Treg infiltration [42]. Induction of FASL thereby strengthens the tumor's immune evasion capabilities.

The relationship between the immune system and angiogenesis is bidirectional, so immune cells may also have an impact on angiogenesis. For example, TAMs produce factors that promote lymph-angiogenesis and angiogenesis (in response to hypoxia) [45]. These macrophages release pro-matrix metalloproteinase-9 (pro-MMP-9) a key angiogenesis promoter within the TME [46]. M2 macrophages also release proangiogenic growth factors, such as IL-8 and VEGF [27]. In OC, a high ratio of M2/M1 TAMs is associated with more advanced stages of disease and poor prognosis [47].

Antiangiogenic therapy can play a major role in reversing the negative effects of VEGF both in angiogenesis and immune suppression. Experimental research has shown that the administration of bevacizumab can reverse the maturation defect of DCs [48]. In OC cell lines, the inhibition of VEGF production leads to a reduction in the expression of the immunosuppressive ganglioside GD3 and the activation of NK T cells [49]. In addition, blocking VEGF can transiently normalize the tortuous vasculature of the tumor, reducing hypoxia and allowing greater infiltration of immune cells (Fig. 3) [42, 50].

Preclinical data strongly suggest that antiangiogenic treatment facilitates the arrival of immune effectors and reduces the presence of myeloid cells involved in immune suppression, which could translate into a possible synergistic effect with immunomodulators [51]. This has been demonstrated in a number of in vivo cancer models, including breast cancer, pancreatic neuroendocrine tumors, colon cancer, small-cell lung cancer, renal cell carcinoma, and melanoma whereby the administration of immunotherapy (cancer vaccine, adoptive cell therapy, a PD-1 or PD-L1 inhibitor, or a CTLA-4 inhibitor) and antiangiogenic agents showed more marked antitumor activity than the administration of either strategy alone [52, 53, 54, 55, 56, 57, 58, 59]. However, there are few in vivo studies in animal models of OC, probably because the development of genetically engineered animal models of OC has lagged far behind their development in other tumor types [60]. One of the few available animal studies used a 
Fig. 3 Vascular normalization with antiangiogenic therapy [42]. Modified from Khan and Kerbel, 2018
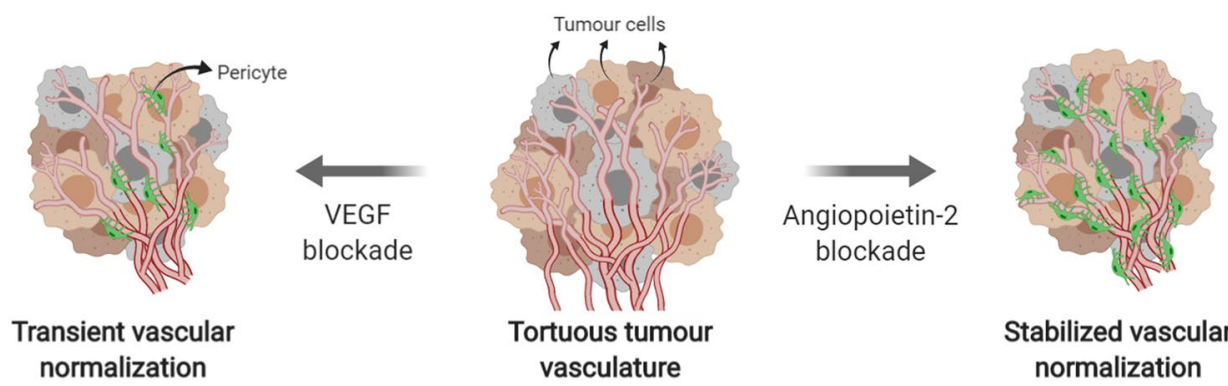

vasculature
vartus tumour

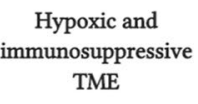

$\downarrow$ Hypoxia
$\uparrow$ Tumor perfusion
$\uparrow$ Immune cell infiltration
$\downarrow$ MDSC recruitment
Shift TAM phenotype from M2-like
to M1-like murine model of epithelial OC to show that 3TSR (a thrombospondin-1 peptide) induced vascular normalization, which enhanced the effect of an oncolytic virus (Newcastle disease virus) by augmenting immunosuppression within the TME [61]. Animals treated with the combination showed more tumor regression, less ascites development, and a lower rate of metastasis [61].

Soto-Ortiz and Finlay developed an interesting mathematical model with the aim of identifying the therapeutic window of two different approaches to cancer treatment: antiangiogenesis and immunotherapy. The model predicted a synergistic effect of both strategies, the most effective treatment would consist of the combination of an anti-VEGF to interrupt the angiogenic process, limiting tumor growth, and the administration of DCs that would increase the cytotoxicity of CD8 $+\mathrm{T}$ cells and would enhance tumor regression [62].

Taken together, these data suggest that antiangiogenic therapy can help shift the OC phenotype from an immunologically "cold" tumor to a "hot" one that is more susceptible to immunotherapy. Clinical studies provide consistent evidence of durable responses with the combination of antiangiogenic therapy and immune checkpoint inhibitors in patients with in other tumor types, such as renal cell carcinoma (RCC) [63], non-small-cell lung cancer [64], or endometrial cancer [65]. To sum up, the theoretical synergism and proven clinical effects in other cancers support clinical investigation of immunotherapy and antiangiogenic therapy in patients with OC.

\section{Clinical evidence for antiangiogenic therapy in ovarian cancer}

There are three groups of antiangiogenic drugs based on their mechanism of action: VEGF inhibitors (bevacizumab), VEGF receptor tyrosine kinase inhibitors (cediranib, pazopanib, sorafenib, and nintedanib), and angiopoietin inhibitors (trebananib) [17]. Data from randomized comparative studies with these agents show a benefit with antiangiogenesis therapy in patients with OC (Tables 1 and 2), but to date, only bevacizumab has been approved in this disease $[66,67,68,69,70$, $71,72,7374]$. Its approval for use as first-line therapy in combination with chemotherapy and as subsequent maintenance was based on the results of the ICON7 and GOG218 phase III studies $[68,72]$. These studies showed that the addition of bevacizumab significantly prolonged progression-free survival (PFS) compared with chemotherapy alone $[68,72]$. Although the addition of bevacizumab had no impact on overall survival (OS) in the overall patient populations, OS was increased in the high-risk subgroup of the ICON7 study (defined as patients on stage IV or III with a residual disease after surgery $>1 \mathrm{~cm}$ ) and in the stage IV subgroup of the GOG218 study [68, 72].

Other phase III trials have confirmed the benefit of bevacizumab (added to chemotherapy and as subsequent maintenance) in patients with "platinum-sensitive" and "platinumresistant" relapses [66, 69, 74]. Results of a recently published randomized study suggest that adding bevacizumab to chemotherapy after platinum-sensitive relapse in patients pretreated with bevacizumab also significantly increases PFS [73].

As described earlier, other phase III studies with positive results have been published with different antiangiogenic agents (Table 2) [75, 76, 77, 78, 79]. However, none of these agents has been submitted to regulatory agencies for approval in OC, suggesting that these agents currently have no clear or obvious advantage over bevacizumab.

\section{Clinical evidence for immunotherapy in ovarian cancer}

Immunotherapy with PD-1 or PD-L1 inhibitors is at an earlier stage in OC compared with other neoplasms, where these agents are now standard treatment, such as melanoma 


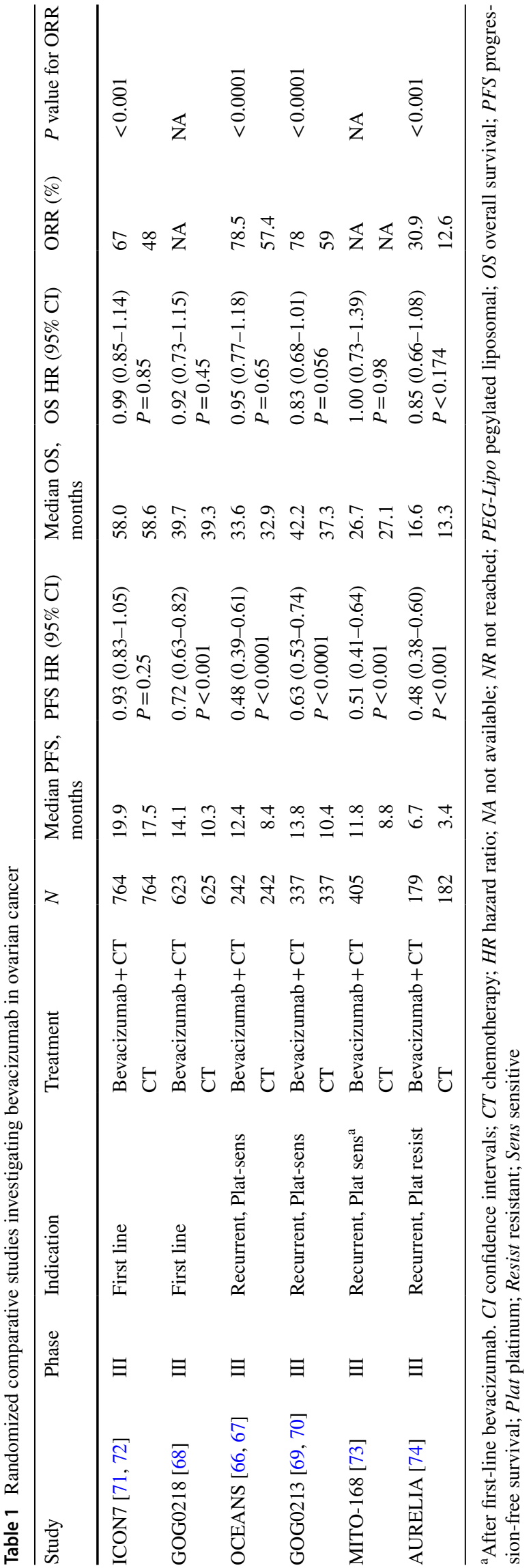

or lung cancer $[80,81]$. Therefore, clinical experience with immunotherapies in OC is limited compared with antiangiogenic therapy. To date, all published studies with immunotherapy are phase I or II studies using PD-1 or PD-L1 inhibitors in patients with recurrent OC (Table 3) [82, 83, $84,85,86,87]$. The effects of immunomodulators as monotherapy in OC recurrence are modest, with ORRs ranging from 8 to $22 \%$ [ $82,83,84,85,86,87]$. Although in one study ORR was higher in patients with higher tumor PD-L1 expression [87], the predictive value of PD-L1 in OC is not yet well established.

Where reported, PFS in the early studies with PD-1 or PD-L1 inhibitors ranged from 1.9 to 3.5 months, and OS from 10.3 to 20.0 months [82, 83, 84, 86, 88], as would be expected in a heavily pretreated population with advanced disease. Consistent with findings in other tumor types, some patients with OC experience prolonged responses to PD-1 or PD-L1 inhibitors [82, 83, 84, 86].

OC is not a particularly immunogenic cancer, so different approaches have been investigated to convert this tumor into a "hot tumor"-one that is a better target for immune checkpoint inhibitors. One approach that has been trialed is to use chemotherapeutic agents. Adding a PD-L1 inhibitor, avelumab, to treatment with pegylated liposomal doxorubicin (PLD) was no more effective than PLD or avelumab alone in the JAVELIN Ovarian 200 trial in women with platinum-resistant relapsed OC [89].The JAVELIN Ovarian 100 study, which was investigating carboplatin + paclitaxel + avelumab in previously untreated patients with epithelial OC, was stopped prematurely by the sponsor because an interim analysis showed that results did not support the primary hypothesis.

Based on the results obtained so far with PD-1/PD-L1 checkpoint inhibitors in OC, there is a need to test new combinations or sequential therapy to improve these results. Poly ADP ribose polymerase (PARP) inhibitors (olaparib, niraparib, and rucaparib) have been approved by regulatory agencies as maintenance treatment after a response to a platinum combination in recurrent disease, both in patients with and without $B R C A$ mutation, after having demonstrated a significant prolongation of PFS. There is emerging preclinical [90] and clinical [91, 92, 93, 94] evidence that the combination of a PARP inhibitor with an antiangiogenic agent or immune checkpoint inhibitor achieves a synergistic effect.

The combination of a PARP inhibitor with a PD-1/ PD-L1 inhibitor has been investigated in the MEDIOLA study [95]. This study found that the combination of olaparib with a PD-L1 inhibitor, durvalumab, was generally well tolerated in patients with platinumsensitive relapsed OC and associated with a $63 \%$ ORR [95], which is higher than with other combinations in the same population. Similarly, the TOPACIO/Keynote 162 study reported promising tumor response rates with 
Table 2 Randomized comparative phase III studies investigating antiangiogenic therapies other than bevacizumab in ovarian cancer

\begin{tabular}{|c|c|c|c|}
\hline Agent (study) & Clinical situation & PFS HR $(95 \%$ CI $)$ & OS HR $(95 \% \mathrm{CI})$ \\
\hline $\begin{array}{l}\text { Nintedanib with chemotherapy and as maintenance (AGO- } \\
\text { OVAR 12) [75] }\end{array}$ & First line & $\begin{array}{l}0.84(0.72-0.98) \\
P=0.024\end{array}$ & NA \\
\hline Pazopanib as maintenance only (AGO-OVAR) [79] & First line & $\begin{array}{l}0.77(0.64-0.91) \\
P=0.002\end{array}$ & $\begin{array}{l}1.08(0.87-1.33) \\
P=0.499\end{array}$ \\
\hline Cediranib (ICON 6) [76] & Recurrent, platinum-sensitive & $\begin{array}{l}0.56(0.44-0.72) \\
P<0.0001\end{array}$ & $\begin{array}{l}0.77(0.55-1.07) \\
P=0.11\end{array}$ \\
\hline Trebananib (TRINOVA-1) ${ }^{\mathrm{a}}[77,78,108]$ & $\begin{array}{l}\text { Recurrent, platinum-free interval } \\
0-12 \text { months }\end{array}$ & $\begin{array}{l}0.70(0.61-0.80) \\
P<0.001\end{array}$ & $\begin{array}{l}0.95(0.81-1.11) \\
P=0.52\end{array}$ \\
\hline
\end{tabular}

All hazard ratios are vs the control group in each study

CI confidence intervals; HR hazard ratio; NA not available; $O S$ overall survival; PFS progression-free survival

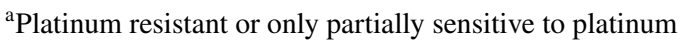

Table 3 Published studies investigating immunotherapies in ovarian cancer

\begin{tabular}{|c|c|c|c|c|c|c|c|c|c|}
\hline \multirow[t]{2}{*}{ Study } & \multirow[t]{2}{*}{ Phase } & \multirow[t]{2}{*}{ Indication } & \multirow[t]{2}{*}{ Treatment } & \multirow[t]{2}{*}{$\mathrm{N}$} & \multicolumn{3}{|l|}{ ORR (\%) } & \multirow{2}{*}{$\begin{array}{l}\text { Median } \\
\text { PFS, } \\
\text { months }\end{array}$} & \multirow{2}{*}{$\begin{array}{l}\text { Median } \\
\text { OS, } \\
\text { months }\end{array}$} \\
\hline & & & & & All patients & $\begin{array}{l}\text { PD-1+ or } \\
\text { PD-L1+ } \\
\text { patients }\end{array}$ & $\begin{array}{l}\text { PD-1- or } \\
\text { PD-L1- } \\
\text { patients }\end{array}$ & & \\
\hline \multicolumn{10}{|l|}{ Pembrolizumab } \\
\hline ECHO-202 [85] & $\mathrm{I} / \mathrm{II}$ & $\begin{array}{l}\text { Advanced/ recur- } \\
\text { rent OC; no prior } \\
\text { CI }\end{array}$ & $\begin{array}{c}\text { Pembrolizumab }+ \\
\text { epacadostat }\end{array}$ & 29 & 8 & NA & NA & NA & NA \\
\hline $\begin{array}{l}\text { KEYNOTE-100 } \\
\text { [87] }\end{array}$ & II & $\begin{array}{l}\text { Recurrent } \\
\text { platinum-resistant } \\
\text { OC }\end{array}$ & Pembrolizumab & 376 & 8 & $17.1^{\mathrm{a}}$ & NA & $2.1^{\mathrm{b}}$ & $17.6^{\mathrm{b}}$ \\
\hline $\begin{array}{l}\text { KEYNOTE-028 } \\
\text { [86] }\end{array}$ & $\mathrm{Ib}$ & $\begin{array}{l}\text { Recurrent } \\
\text { treatment-resist- } \\
\text { ant PD-1+ OC, } \\
\text { fallopian tube or } \\
\text { peritoneal cancer }\end{array}$ & Pembrolizumab & 26 & 11.5 & 11.5 & - & 1.9 & 13.8 \\
\hline \multicolumn{10}{|l|}{ Atezolizumab } \\
\hline Infante et al. [84] & Ia & Recurrent OC & Atezolizumab & 12 & 22 & NA & NA & 2.9 & 11.3 \\
\hline \multicolumn{10}{|l|}{ Avelumab } \\
\hline JAVELIN [88] & $\mathrm{Ib}$ & $\begin{array}{l}\text { Recurrent or refrac- } \\
\text { tory OC }(77 \% \\
\text { PD-L1+) }\end{array}$ & Avelumab & 124 & 9.7 & 12.3 & 5.9 & 2.6 & 10.8 \\
\hline \multicolumn{10}{|l|}{ Nivolumab } \\
\hline $\begin{array}{l}\text { Hamanishi et al. } \\
\text { [83] }\end{array}$ & II & $\begin{array}{l}\text { Platinum-resistant } \\
\text { recurrent OC }\end{array}$ & $\begin{array}{l}\text { Nivolumab } 1 \text { or } 3 \\
\mathrm{mg} / \mathrm{kg}\end{array}$ & 20 & 15 & $12.5(n=2 / 16)$ & $25(n=1 / 4)$ & 3.5 & 20.0 \\
\hline
\end{tabular}

$N A$ not available; $O C$ ovarian cancer; $O R R$ objective response rate; $O S$ overall survival; $P D-(L) 1+$ tumors expressing programmed death protein (ligand)-1; $P D-(L) 1$ - tumors not expressing programmed death protein (ligand)-1; $P F S$ progression-free survival

${ }^{a}$ This is the ORR for the subgroup of patients with a combined positive score (CPS) of $\geq 10$, i.e., the highest level of PDL- 1 expression $(n=82)$

${ }^{b}$ PFS and OS data were reported separately for the two study cohorts: cohort A had received 1-3 prior lines of therapy, and were platinum- or treatment-free for 3-12 months at baseline, and cohort B had received 4-6 prior therapy lines and had a platinum- or treatment-free interval at baseline of $\geq 3$ months. Median PFS was 2.1 months in both cohorts. Median OS was not reached for cohort A; the median OS reported here is for cohort B

the combination of the PARP inhibitor niraparib and the PD-1 inhibitor pembrolizumab in patients with platinumresistant relapsed OC [96]. Ongoing phase III studies with combinations of a PARP inhibitor and immunotherapy will confirm whether this approach is superior to standard treatment options. 


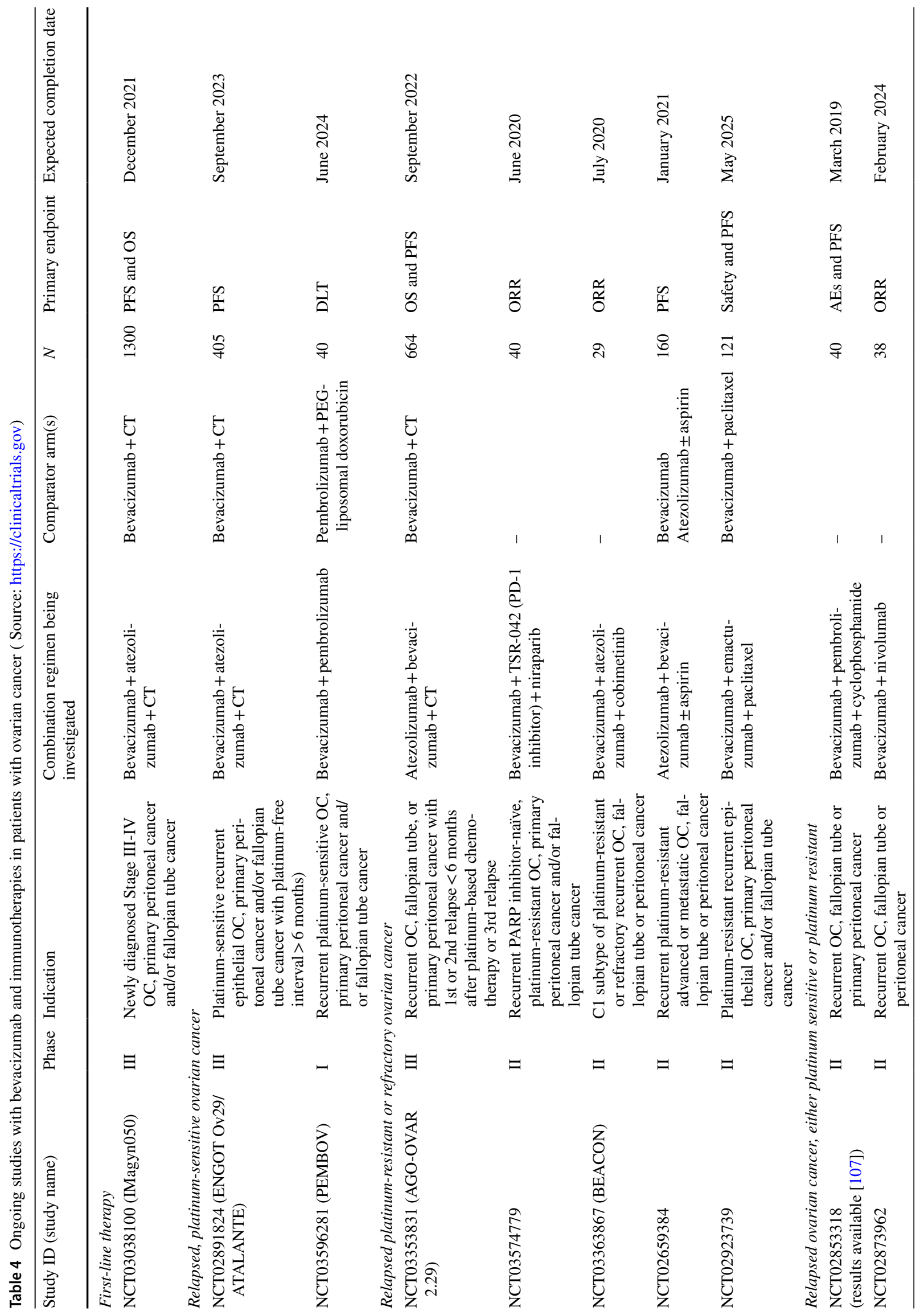




\section{Clinical evidence for combination of antiangiogenic therapy and immunotherapy}

Because of the biological synergism between angiogenesis and tumor-related immune responses, the combination of antiangiogenic therapy and immunotherapy has been investigated in a range of solid tumors, including melanoma [97], RCC [98], biliary tract cancer [99], nonsmall-cell lung cancer [100, 101], and glioblastoma [102]. Although remarkable responses have been reported in individual cases [103], ORRs in clinical trials have been variable, ranging from $4 \%$ with the combination of ramucirumab and pembrolizumab in patients with biliary tract cancer [99] to 55\% with the combination of sunitinib and nivolumab in patients with RCC [98]. In addition, the toxicity profile differs markedly between combinations. Ipilimumab + bevacizumab appears to have a manageable toxicity profile [97, 102]. However, nivolumab + sunitinib was poorly tolerated, with a high incidence of Grade 3 or 4 adverse events $(\sim 70$ to $80 \%)[98,101]$.

To date, data on the combination of antiangiogenic therapy and immunotherapy in patients with OC are limited. A case report described a marked and long-lasting response in a patient with relapsed OC who received nivolumab and pazopanib. Interesting, one of the prior regimens this patient had received (and responded to) was a PARP inhibitor (olaparib) with nivolumab [104]. A phase I dose-escalation study was published investigating two combinations, durvalumab + cediranib and durvalumab + olaparib in patients with gynecologic cancers, including 19 with OC [105]. Six of the 12 patients treated with durvalumab + cediranib had a partial response, and these partial responses lasted for at least 5 months. Similar antitumor activity was seen in a recent study of nivolumab + bevacizumab in patients with recurrent OC (20 who were platinum-sensitive and 18 platinum-resistant). Overall, eight patients had a confirmed partial response, and another six had stable disease lasting $\geq 6$ months. Median PFS was 9.4 months [106]. Recently, the results of a phase II study with the combination of bevacizumab + pembrolizumab and metronomic cyclophosphamide in 40 women with recurrent OC were presented. The patients were heavily treated, having received a median of five previous lines of treatment. This combination was associated with an ORR of $40 \%$ and a disease control rate of $95 \%$. In this study, the 6-month PFS rate was $100 \%$ in patients who had platinum-sensitive disease and 59\% in those who did not [107].

Since bevacizumab is approved for use in OC, and appears well tolerated when used in combination with immunotherapy in other indications, a number of phase 
Table 5 Ongoing front-line studies with immunotherapies and PARP inhibitors \pm bevacizumab in advanced ovarian cancer ( Source: https://clini caltrials.gov)

\begin{tabular}{|c|c|c|c|c|c|}
\hline $\begin{array}{l}\text { Study ID (study } \\
\text { name(s)) }\end{array}$ & Treatment purpose & Bevacizumab & Target $\mathrm{N}$ & Treatment & $\begin{array}{l}\text { Maintenance (where } \\
\text { applicable) }\end{array}$ \\
\hline $\begin{array}{l}\text { NCT03737643 (DUO-O/ } \\
\text { ENGOT Ov46) }\end{array}$ & $\begin{array}{l}\text { Front line and mainte- } \\
\text { nance }\end{array}$ & $\begin{array}{l}\text { Mandatory, but optional } \\
\text { in patients with } B R C A \\
\text { mutation }\end{array}$ & 1056 & $\begin{array}{l}\mathrm{CP}+\text { bevacizumab } \\
\mathrm{CP}+\text { bevacizumab + dur- } \\
\text { valumab } \\
\mathrm{CP}+\text { bevacizumab + dur- } \\
\text { valumab } \\
\mathrm{CP}+\text { bevacizumab + dur- } \\
\text { valumab }\end{array}$ & $\begin{array}{l}\text { Bevacizumab } \\
\text { Bevacizumab + dur- } \\
\text { valumab } \\
\text { Bevacizumab + dur- } \\
\text { valumab + olaparib } \\
\text { Bevacizumab + dur- } \\
\text { valumab + olaparib }\end{array}$ \\
\hline $\begin{array}{l}\text { NCT03740165 (KEY- } \\
\text { LYNK-001/ENGOT } \\
\text { Ov43) }\end{array}$ & $\begin{array}{l}\text { Front line and mainte- } \\
\text { nance }\end{array}$ & Optional $^{\mathrm{a}}$ & 1086 & $\begin{array}{l}\mathrm{CP}+\text { pembrolizumab } \\
\mathrm{CP}+\text { pembrolizumab } \\
\mathrm{CP}+\mathrm{PL}-\text { pembrolizumab }\end{array}$ & $\begin{array}{l}\text { Pembrolizumab + olaparib } \\
\text { Pembrolizumab + PL- } \\
\text { olaparib } \\
\text { PL-pembrolizumab + PL- } \\
\text { olaparib }\end{array}$ \\
\hline $\begin{array}{l}\text { NCT03602859 (FIRST/ } \\
\text { ENGOT Ov44) }\end{array}$ & $\begin{array}{l}\text { Front line and mainte- } \\
\text { nance }\end{array}$ & Optional $^{\mathrm{a}}$ & 912 & $\begin{array}{l}\mathrm{CP}+\text { dostarlimab } \\
\mathrm{CP}+\text { PL-dostarlimab } \\
\mathrm{CP}+\text { PL-dostarlimab }\end{array}$ & $\begin{array}{l}\text { Dostarlimab + niraparib } \\
\text { PL-dostarlimab + niraparib } \\
\text { PL-dostarlimab + PL- } \\
\text { niraparib }\end{array}$ \\
\hline $\begin{array}{l}\text { NCT03522246 } \\
\text { (ATHENA/GOG 3020/ } \\
\text { ENGOT Ov45) }\end{array}$ & $\begin{array}{l}\text { Only maintenance after } \\
\text { front line }{ }^{c}\end{array}$ & $\begin{array}{l}\text { Prohibited during main- } \\
\text { tenance }\end{array}$ & 1012 & & $\begin{array}{l}\text { Rucaparib + nivolumab } \\
\text { Rucaparib + PL-nivolumab } \\
\text { PL-rucaparib + nivolumab } \\
\text { PL-rucaparib + PL- } \\
\text { nivolumab }\end{array}$ \\
\hline
\end{tabular}

$C P$ carboplatin + paclitaxel; ENGOT The European Network for Gynaecological Oncological Trial groups; $P L$ placebo

a'Likely to become mandatory (see "Discussion" section)

${ }^{\mathrm{b}} B R C A$-mutated patients will be randomized only to the active treatment arms, and not to the standard of care (carboplatin + paclitaxel) plus placebo arm

${ }^{c}$ Front-line platinum-based chemotherapy; patients were required to have a response to front-line treatment

II and phase III clinical studies are currently underway to investigate the use of bevacizumab in combination with immunotherapeutic agents (Table 4).

In addition to these, several ongoing Phase III first-line trials are currently evaluating the possible benefit of adding checkpoint inhibitors to chemotherapy, followed by maintenance therapy with these plus a PARP inhibitor. However, only one of these trials requires mandatory use of bevacizumab (DUO-O/ENGOT Ov46 study) (Table 5). Although the use of bevacizumab is optional and at the investigator's discretion in two other studies (First/ENGOT Ov44 and ENGOT Ov43), it is expected that their protocols will be revised to make treatment with bevacizumab mandatory, in light of the results of the Javelin 100 and Javelin 200 studies. The fourth study (Athena/ENGOT Ov45) explores an immunotherapy and/or a PARP inhibitor only in a maintenance setting without bevacizumab. The aim of these studies is to assess the potential synergism between PARP inhibitors and immunotherapy (plus bevacizumab in some of them), since adding only immunomodulators to chemotherapy has not shown benefit in OC.

As well as defining the efficacy and safety profile of antiangiogenic and immunotherapy combinations, future research needs to validate predictive biomarkers for these combinations in OC and clarify the molecular basis for resistance to immunotherapy.

\section{Conclusions}

There is a strong biological rationale for combining immunotherapy with antiangiogenic agents in the treatment of OC, but clinical experience with this combination is limited so far. The results of ongoing studies will clarify the role of such combinations in patients with OC.

Acknowledgements We would like to thank Eliana Mesa and Catherine Rees of Springer Healthcare Communications who edited the manuscript. The editorial assistance was funded by Roche. No other funding from funding agencies in the public, commercial, or not-forprofit sectors was received in the preparation of this manuscript.

Author contributions Drs Antonio Casado, Elena García-Martínez, Josep Piulats, Andres Redondo, and Analía Rodríguez participated in the conception of the manuscript, in the production of this manuscript, its revision, and final approval for publication.

Funding Dr Elena García-Martínez has acted as a consultant or advisor for Roche, AstraZeneca, and Clovis; her department received research 
funding from Roche; spoken on behalf of Roche and Pharmamar; received financial support for education programs from Roche and AstraZeneca; and received financial support for attending symposia from Roche, AstraZeneca, Pharmamar, Pfizer, Bristol, and Merck Sharp \& Dohme (MSD). Dr Andres Redondo has acted as a consultant or advisor for Roche, AstraZeneca, Tesaro, Clovis, Pharmamar, Lilly, Novartis, and Eisai; received research funding from Roche, Pharmamar, and Eisai; spoken on behalf of Roche, AstraZeneca, Tesaro, Pharmamar, and Novartis; and received funding for registration and attendance at scientific meetings from Roche, AstraZeneca, Tesaro, and Pharmamar. Dr Josep M Piulats has acted as a consultant or advisor for Roche, Novartis, Bristol Myers Squibb, MSD, Merck Serono, AstraZeneca, Clovis, VCN Biosciences, Janssen, Astellas, Bayer, Sanofi Genzyme, and Pfizer; received research funding from Pfizer, Merck Serono, MSD, Bristol Myers Squibb, Incyte, VCN Biosciences, Astellas, and Janssen; and received financial support for attending symposia from Roche, Janssen, and Ipsen. Analia Rodriguez is an employee of Roche Farma, Spain. Dr Antonio Casado has received support from Pharmamar, Lilly, Roche, AstraZeneca, and Novartis to attend international meeting or to organize meetings; the institution in which Dr. Antonio Casado works received funds for clinical and translational research

Open Access This article is licensed under a Creative Commons Attribution 4.0 International License, which permits use, sharing, adaptation, distribution and reproduction in any medium or format, as long as you give appropriate credit to the original author(s) and the source, provide a link to the Creative Commons licence, and indicate if changes were made. The images or other third party material in this article are included in the article's Creative Commons licence, unless indicated otherwise in a credit line to the material. If material is not included in the article's Creative Commons licence and your intended use is not permitted by statutory regulation or exceeds the permitted use, you will need to obtain permission directly from the copyright holder. To view a copy of this licence, visit http://creativecommons.org/licenses/by/4.0/.

\section{References}

1. Ferlay J, Colombet M, Soerjomataram I, Mathers C, Parkin DM, Pineros M, Znaor A, Bray F (2019) Estimating the global cancer incidence and mortality in 2018: GLOBOCAN sources and methods. Int J Cancer 144(8):1941-1953. https://doi. org/10.1002/ijc.31937

2. FIGO (2019) Global ovarian cancer rates rising. Int Fed Gynecol Obstet. https://www.figo.org/global-ovarian-cancer-rates-rising. Accessed May 262020

3. Gabra H (2014) Introduction to managing patients with recurrent ovarian cancer. EJC Suppl 12(2):2-6. https://doi.org/10.1016/ S1359-6349(15)70003-0

4. Banerjee S, Kaye SB (2013) New strategies in the treatment of ovarian cancer: current clinical perspectives and future potential. Clin Cancer Res 19(5):961-968. https://doi.org/10.1158/10780432.CCR-12-2243

5. Faraoni I, Graziani G (2018) Role of BRCA mutations in cancer treatment with poly(ADP-ribose) polymerase (PARP) inhibitors. Cancers (Basel). https://doi.org/10.3390/cancers10120487

6. Bamberger ES, Perrett CW (2002) Angiogenesis in epithelian ovarian cancer. Mol Pathol 55(6):348-359

7. Chen DS, Mellman I (2017) Elements of cancer immunity and the cancer-immune set point. Nature 541(7637):321-330. https ://doi.org/10.1038/nature21349

8. Rodriguez GM, Galpin KJC, McCloskey CW, Vanderhyden BC (2018) The tumor microenvironment of epithelial ovarian cancer and its influence on response to immunotherapy. Cancers (Basel). https://doi.org/10.3390/cancers10080242

9. Fukumura D, Kloepper J, Amoozgar Z, Duda DG, Jain RK (2018) Enhancing cancer immunotherapy using antiangiogenics: opportunities and challenges. Nat Rev Clin Oncol 15(5):325340. https://doi.org/10.1038/nrclinonc.2018.29

10. Hida K, Maishi N, Torii C, Hida Y (2016) Tumor angiogenesis-characteristics of tumor endothelial cells. Int J Clin Oncol 21(2):206-212. https://doi.org/10.1007/s10147-016-0957-1

11. Hanahan D, Folkman J (1996) Patterns and emerging mechanisms of the angiogenic switch during tumorigenesis. Cell 86(3):353-364

12. Rajabi M, Mousa SA (2017) The role of angiogenesis in cancer treatment. Biomedicines. https://doi.org/10.3390/biomedicin es5020034

13. Murakami M, Simons M (2008) Fibroblast growth factor regulation of neovascularization. Curr Opin Hematol 15(3):215-220. https://doi.org/10.1097/MOH.0b013e3282f97d98

14. Potente M, Gerhardt H, Carmeliet P (2011) Basic and therapeutic aspects of angiogenesis. Cell 146(6):873-887. https://doi. org/10.1016/j.cell.2011.08.039

15. Krock BL, Skuli N, Simon MC (2011) Hypoxia-induced angiogenesis: good and evil. Genes Cancer 2(12):1117-1133. https:// doi.org/10.1177/1947601911423654

16. LaGory EL, Giaccia AJ (2016) The ever-expanding role of HIF in tumour and stromal biology. Nat Cell Biol 18(4):356-365. https ://doi.org/10.1038/ncb3330

17. Monk BJ, Minion LE, Coleman RL (2016) Anti-angiogenic agents in ovarian cancer: past, present, and future. Ann Oncol 27(Suppl 1):i33-i39. https://doi.org/10.1093/annonc/mdw093

18. Mukherjee S, Pal M, Mukhopadhyay S, Das I, Hazra R, Ghosh S, Mondal RK, Bal R (2017) VEGF expression to support targeted therapy in ovarian surface epithelial neoplasms. J Clin Diagn Res 11(4):EC43-EC46. https://doi.org/10.7860/JCDR/2017/24670 .9737

19. Kipps E, Tan DS, Kaye SB (2013) Meeting the challenge of ascites in ovarian cancer: new avenues for therapy and research. Nat Rev Cancer 13(4):273-282. https://doi.org/10.1038/nrc3432

20. Bamias A, Koutsoukou V, Terpos E, Tsiatas ML, Liakos C, Tsitsilonis O, Rodolakis A, Voulgaris Z, Vlahos G, Papageorgiou T, Papatheodoridis G, Archimandritis A, Antsaklis A, Dimopoulos MA (2008) Correlation of NK T-like CD3+CD56+ cells and CD4+CD25+(hi) regulatory $\mathrm{T}$ cells with VEGF and TNFalpha in ascites from advanced ovarian cancer: association with platinum resistance and prognosis in patients receiving first-line, platinum-based chemotherapy. Gynecol Oncol 108(2):421-427. https://doi.org/10.1016/j.ygyno.2007.10.018

21. Imai Y, Hasegawa K, Matsushita H, Fujieda N, Sato S, Miyagi E, Kakimi K, Fujiwara K (2018) Expression of multiple immune checkpoint molecules on $\mathrm{T}$ cells in malignant ascites from epithelial ovarian carcinoma. Oncol Lett 15(5):6457-6468. https:// doi.org/10.3892/ol.2018.8101

22. Mikula-Pietrasik J, Uruski P, Szubert S, Szpurek D, Sajdak S, Tykarski A, Ksiazek K (2017) Malignant ascites determine the transmesothelial invasion of ovarian cancer cells. Int J Biochem Cell Biol 92:6-13. https://doi.org/10.1016/j.biocel.2017.09.002

23. Trachana SP, Pilalis E, Gavalas NG, Tzannis K, Papadodima O, Liontos M, Rodolakis A, Vlachos G, Thomakos N, Haidopoulos D, Lykka M, Koutsoukos K, Kostouros E, Terpos E, Chatziioannou A, Dimopoulos MA, Bamias A (2016) The development of an angiogenic protein "Signature" in ovarian cancer ascites as a tool for biologic and prognostic profiling. PLoS ONE 11(6):e0156403. https://doi.org/10.1371/journal.pone.0156403

24. Worzfeld T, Pogge von Strandmann E, Huber M, Adhikary T, Wagner U, Reinartz S, Muller R (2017) The unique molecular 
and cellular microenvironment of ovarian cancer. Front Oncol 7:24. https://doi.org/10.3389/fonc.2017.00024

25. Finkernagel F, Reinartz S, Lieber S, Adhikary T, Wortmann A, Hoffmann N, Bieringer T, Nist A, Stiewe T, Jansen JM, Wagner U, Muller-Brusselbach S, Muller R (2016) The transcriptional signature of human ovarian carcinoma macrophages is associated with extracellular matrix reorganization. Oncotarget 7(46):75339-75352. https://doi.org/10.18632/oncotarget.12180

26. Meza-Perez S, Randall TD (2017) Immunological functions of the omentum. Trends Immunol 38(7):526-536. https://doi. org/10.1016/j.it.2017.03.002

27. Biswas SK, Mantovani A (2010) Macrophage plasticity and interaction with lymphocyte subsets: cancer as a paradigm. Nat Immunol 11(10):889-896. https://doi.org/10.1038/ni.1937

28. Facciabene A, Motz GT, Coukos G (2012) T-regulatory cells: key players in tumor immune escape and angiogenesis. Cancer Res 72(9):2162-2171. https://doi.org/10.1158/0008-5472. CAN-11-3687

29. Goode EL, Block MS, Kalli KR, Vierkant RA, Chen W, Fogarty ZC, Gentry-Maharaj A, Toloczko A, Hein A, Bouligny AL, Jensen A, Osorio A, Hartkopf A, Ryan A, Chudecka-Glaz A, Magliocco AM, Hartmann A, Jung AY, Gao B, Hernandez BY, Fridley BL, McCauley BM, Kennedy CJ, Wang C, Karpinskyj C, de Sousa CB, Tiezzi DG, Wachter DL, Herpel E, Taran FA, Modugno F, Nelson G, Lubinski J, Menkiszak J, Alsop J, Lester J, Garcia-Donas J, Nation J, Hung J, Palacios J, Rothstein JH, Kelley JL, de Andrade JM, Robles-Diaz L, Intermaggio MP, Widschwendter M, Beckmann MW, Ruebner M, Jimenez-Linan M, Singh N, Oszurek O, Harnett PR, Rambau PF, Sinn P, Wagner P, Ghatage P, Sharma R, Edwards RP, Ness RB, Orsulic S, Brucker SY, Johnatty SE, Longacre TA, Ursula E, McGuire V, Sieh W, Natanzon Y, Li Z, Whittemore AS, Anna A, Staebler A, Karlan BY, Gilks B, Bowtell DD, Hogdall E, Candido dos Reis FJ, Steed H, Campbell IG, Gronwald J, Benitez J, Koziak JM, Chang-Claude J, Moysich KB, Kelemen LE, Cook LS, Goodman MT, Garcia MJ, Fasching PA, Kommoss S, Deen S, Kjaer SK, Menon U, Brenton JD, Pharoah PDP, Chenevix-Trench G, Huntsman DG, Winham SJ, Kobel M, Ramus SJ (2017) Dose-response association of $\mathrm{CD} 8+$ tumor-infiltrating lymphocytes and survival time in high-grade serous ovarian cancer. JAMA Oncol 3(12):e173290. https://doi.org/10.1001/jamaoncol.2017.3290

30. Jimenez-Sanchez A, Memon D, Pourpe S, Veeraraghavan $\mathrm{H}, \mathrm{Li}$ Y, Vargas HA, Gill MB, Park KJ, Zivanovic O, Konner J, Ricca J, Zamarin D, Walther T, Aghajanian C, Wolchok JD, Sala E, Merghoub T, Snyder A, Miller ML (2017) Heterogeneous tumorimmune microenvironments among differentially growing metastases in an ovarian cancer patient. Cell 170(5):927-938e920. https://doi.org/10.1016/j.cell.2017.07.025

31. Bedard PL, Hansen AR, Ratain MJ, Siu LL (2013) Tumour heterogeneity in the clinic. Nature 501(7467):355-364. https://doi. org/10.1038/nature 12627

32. Zhang L, Conejo-Garcia JR, Katsaros D, Gimotty PA, Massobrio M, Regnani G, Makrigiannakis A, Gray H, Schlienger K, Liebman MN, Rubin SC, Coukos G (2003) Intratumoral T cells, recurrence, and survival in epithelial ovarian cancer. N Engl $\mathbf{J}$ Med 348(3):203-213. https://doi.org/10.1056/NEJMoa020177

33. Darb-Esfahani S, Kunze CA, Kulbe H, Sehouli J, Wienert S, Lindner J, Budczies J, Bockmayr M, Dietel M, Denkert C, Braicu I, Johrens K (2016) Prognostic impact of programmed cell death-1 (PD-1) and PD-ligand 1 (PD-L1) expression in cancer cells and tumor-infiltrating lymphocytes in ovarian high grade serous carcinoma. Oncotarget 7(2):1486-1499. https://doi. org/10.18632/oncotarget.6429

34. Zhu J, Wen H, Bi R, Wu Y, Wu X (2017) Prognostic value of programmed death-ligand 1 (PD-L1) expression in ovarian clear cell carcinoma. J Gynecol Oncol 28(6):e77. https://doi.org/10.3802/ jgo.2017.28.e77

35. Wang Q, Lou W, Di W, Wu X (2017) Prognostic value of tumor PD-L1 expression combined with CD8(+) tumor infiltrating lymphocytes in high grade serous ovarian cancer. Int Immunopharmacol 52:7-14. https://doi.org/10.1016/j.intimp.2017.08.017

36. Xiang X, Yu PC, Long D, Liao XL, Zhang S, You XM, Zhong JH, Li LQ (2018) Prognostic value of PD -L1 expression in patients with primary solid tumors. Oncotarget 9(4):5058-5072. https://doi.org/10.18632/oncotarget.23580

37. Hamanishi J, Mandai M, Iwasaki M, Okazaki T, Tanaka Y, Yamaguchi K, Higuchi T, Yagi H, Takakura K, Minato N, Honjo T, Fujii S (2007) Programmed cell death 1 ligand 1 and tumorinfiltrating CD8+ T lymphocytes are prognostic factors of human ovarian cancer. Proc Natl Acad Sci USA 104(9):3360-3365. https://doi.org/10.1073/pnas.0611533104

38. Goodman AM, Kato S, Bazhenova L, Patel SP, Frampton GM, Miller V, Stephens PJ, Daniels GA, Kurzrock R (2017) Tumor mutational burden as an independent predictor of response to immunotherapy in diverse cancers. Mol Cancer Ther 16(11):2598-2608. https://doi.org/10.1158/1535-7163. MCT-17-0386

39. Strickland KC, Howitt BE, Shukla SA, Rodig S, Ritterhouse LL, Liu JF, Garber JE, Chowdhury D, Wu CJ, D'Andrea AD, Matulonis UA, Konstantinopoulos PA (2016) Association and prognostic significance of BRCA1/2-mutation status with neoantigen load, number of tumor-infiltrating lymphocytes and expression of PD-1/PD-L1 in high grade serous ovarian cancer. Oncotarget 7(12):13587-13598. https://doi.org/10.18632/oncotarget.7277

40. Yarchoan M, Hopkins A, Jaffee EM (2017) Tumor mutational burden and response rate to PD-1 inhibition. N Engl J Med 377(25):2500-2501. https://doi.org/10.1056/NEJMc1713444

41. Gonzalez H, Hagerling C, Werb Z (2018) Roles of the immune system in cancer: from tumor initiation to metastatic progression. Genes Dev 32(19-20):1267-1284. https://doi.org/10.1101/ $\operatorname{gad} .314617 .118$

42. Khan KA, Kerbel RS (2018) Improving immunotherapy outcomes with anti-angiogenic treatments and vice versa. Nat Rev Clin Oncol 15(5):310-324. https://doi.org/10.1038/nrcli nonc.2018.9

43. Li YL, Zhao H, Ren XB (2016) Relationship of VEGF/VEGFR with immune and cancer cells: staggering or forward? Cancer Biol Med 13(2):206-214. https://doi.org/10.20892/j.i ssn.2095-3941.2015.0070

44. Hendry SA, Farnsworth RH, Solomon B, Achen MG, Stacker SA, Fox SB (2016) The role of the tumor vasculature in the host immune response: implications for therapeutic strategies targeting the tumor microenvironment. Front Immunol 7:621. https:// doi.org/10.3389/fimmu.2016.00621

45. Riabov V, Gudima A, Wang N, Mickley A, Orekhov A, Kzhyshkowska J (2014) Role of tumor associated macrophages in tumor angiogenesis and lymphangiogenesis. Front Physiol 5:75. https://doi.org/10.3389/fphys.2014.00075

46. Guo Q, Jin Z, Yuan Y, Liu R, Xu T, Wei H, Xu X, He S, Chen S, Shi Z, Hou W, Hua B (2016) New mechanisms of tumor-associated macrophages on promoting tumor progression: recent research advances and potential targets for tumor immunotherapy. J Immunol Res 2016:9720912. https://doi. org/10.1155/2016/9720912

47. Yuan X, Zhang J, Li D, Mao Y, Mo F, Du W, Ma X (2017) Prognostic significance of tumor-associated macrophages in ovarian cancer: a meta-analysis. Gynecol Oncol 147(1):181-187. https ://doi.org/10.1016/j.ygyno.2017.07.007

48. Osada T, Chong G, Tansik R, Hong T, Spector N, Kumar R, Hurwitz HI, Dev I, Nixon AB, Lyerly HK, Clay T, Morse MA (2008) 
The effect of anti-VEGF therapy on immature myeloid cell and dendritic cells in cancer patients. Cancer Immunol Immunother 57(8):1115-1124. https://doi.org/10.1007/s00262-007-0441-x

49. Tiper IV, Webb TJ (2016) Targeted attack: mechanisms by which ovarian cancers suppress the immune system. TCR 5(Suppl 6):S1305-S1306. https://doi.org/10.21037/tcr.2016.11.62

50. Huang Y, Goel S, Duda DG, Fukumura D, Jain RK (2013) Vascular normalization as an emerging strategy to enhance cancer immunotherapy. Cancer Res 73(10):2943-2948. https://doi. org/10.1158/0008-5472.CAN-12-4354

51. Carman CV, Martinelli R (2015) T lymphocyte-endothelial interactions: emerging understanding of trafficking and antigenspecific immunity. Front Immunol 6:603. https://doi.org/10.3389/ fimmu.2015.00603

52. Allen E, Jabouille A, Rivera LB, Lodewijckx I, Missiaen R, Steri V, Feyen K, Tawney J, Hanahan D, Michael IP, Bergers G (2017) Combined antiangiogenic and anti-PD-L1 therapy stimulates tumor immunity through HEV formation. Sci Transl Med. https ://doi.org/10.1126/scitranslmed.aak9679

53. Courau T, Nehar-Belaid D, Florez L, Levacher B, Vazquez T, Brimaud F, Bellier B, Klatzmann D (2016) TGF-beta and VEGF cooperatively control the immunotolerant tumor environment and the efficacy of cancer immunotherapies. JCI Insight 1(9):e85974. https://doi.org/10.1172/jci.insight.85974

54. Kato Y, Tabata K, Kimura T, Yachie-Kinoshita A, Ozawa Y, Yamada K, Ito J, Tachino S, Hori Y, Matsuki M, Matsuoka Y, Ghosh S, Kitano H, Nomoto K, Matsui J, Funahashi Y (2019) Lenvatinib plus anti-PD-1 antibody combination treatment activates $\mathrm{CD} 8+\mathrm{T}$ cells through reduction of tumor-associated macrophage and activation of the interferon pathway. PLoS ONE 14(2):e0212513. https://doi.org/10.1371/journal.pone.0212513

55. Kwilas AR, Ardiani A, Donahue RN, Aftab DT, Hodge JW (2014) Dual effects of a targeted small-molecule inhibitor (cabozantinib) on immune-mediated killing of tumor cells and immune tumor microenvironment permissiveness when combined with a cancer vaccine. J Transl Med 12:294. https://doi.org/10.1186/ s12967-014-0294-y

56. Meder L, Schuldt P, Thelen M, Schmitt A, Dietlein F, Klein S, Borchmann S, Wennhold K, Vlasic I, Oberbeck S, Riedel R, Florin A, Golfmann K, Schlosser HA, Odenthal M, Buettner R, Wolf J, Hallek M, Herling M, von Bergwelt-Baildon M, Reinhardt HC, Ullrich RT (2018) Combined VEGF and PD-L1 blockade displays synergistic treatment effects in an autochthonous mouse model of small cell lung cancer. Cancer Res 78(15):4270 4281. https://doi.org/10.1158/0008-5472.CAN-17-2176

57. Shrimali RK, Yu Z, Theoret MR, Chinnasamy D, Restifo NP, Rosenberg SA (2010) Antiangiogenic agents can increase lymphocyte infiltration into tumor and enhance the effectiveness of adoptive immunotherapy of cancer. Cancer Res 70(15):61716180. https://doi.org/10.1158/0008-5472.CAN-10-0153

58. Wu FTH, Xu P, Chow A, Man S, Kruger J, Khan KA, Paez-Ribes M, Pham E, Kerbel RS (2019) Pre- and post-operative anti-PDL1 plus anti-angiogenic therapies in mouse breast or renal cancer models of micro- or macro-metastatic disease. Br J Cancer 120(2):196-206. https://doi.org/10.1038/s41416-018-0297-1

59. Yasuda S, Sho M, Yamato I, Yoshiji H, Wakatsuki K, Nishiwada S, Yagita H, Nakajima Y (2013) Simultaneous blockade of programmed death 1 and vascular endothelial growth factor receptor 2 (VEGFR2) induces synergistic anti-tumour effect in vivo. Clin Exp Immunol 172(3):500-506. https://doi.org/10.1111/cei.12069

60. Connolly DC (2010) Animal models of ovarian cancer. In: Stack MS, Fishman DA (eds) Ovarian cáncer. Cancer research and treatment, 2nd edn. Springer, New York, pp 353-391

61. Matuszewska K, Santry LA, van Vloten JP, AuYeung AWK, Major PP, Lawler J, Wootton SK, Bridle BW, Petrik J (2019) Combining vascular normalization with an oncolytic virus enhances immunotherapy in a preclinical model of advancedstage ovarian cancer. Clin Cancer Res 25(5):1624-1638. https:// doi.org/10.1158/1078-0432.CCR-18-0220

62. Soto-Ortiz L, Finley SD (2016) A cancer treatment based on synergy between anti-angiogenic and immune cell therapies. J Theor Biol 394:197-211. https://doi.org/10.1016/j.jtbi.2016.01.026

63. Kuusk T, Albiges L, Escudier B, Grivas N, Haanen J, Powles T, Bex A (2017) Antiangiogenic therapy combined with immune checkpoint blockade in renal cancer. Angiogenesis 20(2):205215. https://doi.org/10.1007/s10456-017-9550-0

64. Socinski MA, Jotte RM, Cappuzzo F, Orlandi F, Stroyakovskiy D, Nogami N, Rodriguez-Abreu D, Moro-Sibilot D, Thomas CA, Barlesi F, Finley G, Kelsch C, Lee A, Coleman S, Deng Y, Shen Y, Kowanetz M, Lopez-Chavez A, Sandler A, Reck M (2018) Atezolizumab for first-line treatment of metastatic nonsquamous NSCLC. N Engl J Med 378(24):2288-2301. https:// doi.org/10.1056/NEJMoa1716948

65. Makker V, Rasco D, Vogelzang NJ, Brose MS, Cohn AL, Mier J, Di Simone C, Hyman DM, Stepan DE, Dutcus CE, Schmidt EV, Guo M, Sachdev P, Shumaker R, Aghajanian C, Taylor M (2019) Lenvatinib plus pembrolizumab in patients with advanced endometrial cancer: an interim analysis of a multicentre, openlabel, single-arm, phase 2 trial. Lancet Oncol 20(5):711-718. https://doi.org/10.1016/S1470-2045(19)30020-8

66. Aghajanian C, Blank SV, Goff BA, Judson PL, Teneriello MG, Husain A, Sovak MA, Yi J, Nycum LR (2012) OCEANS: a randomized, double-blind, placebo-controlled phase III trial of chemotherapy with or without bevacizumab in patients with platinum-sensitive recurrent epithelial ovarian, primary peritoneal, or fallopian tube cancer. J Clin Oncol 30(17):2039-2045. https://doi.org/10.1200/JCO.2012.42.0505

67. Aghajanian C, Goff B, Nycum LR, Wang YV, Husain A, Blank SV (2015) Final overall survival and safety analysis of OCEANS, a phase 3 trial of chemotherapy with or without bevacizumab in patients with platinum-sensitive recurrent ovarian cancer. Gynecol Oncol 139(1):10-16. https://doi.org/10.1016/j.ygyno .2015 .08 .004

68. Burger RA, Brady MF, Bookman MA, Fleming GF, Monk BJ, Huang H, Mannel RS, Homesley HD, Fowler J, Greer BE, Boente M, Birrer MJ, Liang SX (2011) Incorporation of bevacizumab in the primary treatment of ovarian cancer. N Engl J Med 365(26):2473-2483. https://doi.org/10.1056/NEJMoa1104390

69. Coleman RL, Brady MF, Herzog TJ, Sabbatini P, Armstrong DK, Walker JL, Kim BG, Fujiwara K, Tewari KS, O'Malley DM (2015) A phase III randomized controlled clinical trial of carboplatin and paclitaxel alone or in combination with bevacizumab followed by bevacizumab and secondary cytoreductive surgery in platinum-sensitive, recurrent ovarian, peritoneal primary and fallopian tube cancer (Gynecologic Oncology Group 0213). Gynecol Oncol 137(Suppl 1):3-4

70. Coleman RL, Brady MF, Herzog TJ, Sabbatini P, Armstrong DK, Walker JL, Kim BG, Fujiwara K, Tewari KS, O’Malley DM, Davidson SA, Rubin SC, DiSilvestro P, Basen-Engquist K, Huang H, Chan JK, Spirtos NM, Ashfaq R, Mannel RS (2017) Bevacizumab and paclitaxel-carboplatin chemotherapy and secondary cytoreduction in recurrent, platinum-sensitive ovarian cancer (NRG Oncology/Gynecologic Oncology Group study GOG-0213): a multicentre, open-label, randomised, phase 3 trial. Lancet Oncol 18(6):779-791. https://doi.org/10.1016/S1470 $-2045(17) 30279-6$

71. Oza AM, Cook AD, Pfisterer J, Embleton A, Ledermann JA, Pujade-Lauraine E, Kristensen G, Carey MS, Beale P, Cervantes A, Park-Simon TW, Rustin G, Joly F, Mirza MR, Plante M, Quinn M, Poveda A, Jayson GC, Stark D, Swart AM, Farrelly L, Kaplan R, Parmar MK, Perren TJ (2015) Standard chemotherapy with or without bevacizumab for women with newly 
diagnosed ovarian cancer (ICON7): overall survival results of a phase 3 randomised trial. Lancet Oncol 16(8):928-936. https:// doi.org/10.1016/S1470-2045(15)00086-8

72. Perren TJ, Swart AM, Pfisterer J, Ledermann JA, PujadeLauraine E, Kristensen G, Carey MS, Beale P, Cervantes A, Kurzeder C, du Bois A, Sehouli J, Kimmig R, Stahle A, Collinson F, Essapen S, Gourley C, Lortholary A, Selle F, Mirza MR, Leminen A, Plante M, Stark D, Qian W, Parmar MK, Oza AM (2011) A phase 3 trial of bevacizumab in ovarian cancer. N Engl J Med 365(26):2484-2496. https://doi.org/10.1056/NEJMo a1103799

73. Pignata S, Lorusso D, Joly F, Gallo C, Colombo N, Sessa C, Bamias A, Pisano C, Selle F, Zaccarelli E, Scambia G, Pautier P, Nicoletto MO, De Giorgi U, Dubot C, Bologna A, Orditura M, Ray-Coquard IL, Perrone F, Daniele G (2018) Chemotherapy plus or minus bevacizumab for platinum-sensitive ovarian cancer patients recurring after a bevacizumab containing first line treatment: the randomized phase 3 trial MITO16B-MaNGO OV2BENGOT OV17. J Clin Oncol 36(Suppl 15):5506

74. Pujade-Lauraine E, Hilpert F, Weber B, Reuss A, Poveda A, Kristensen G, Sorio R, Vergote I, Witteveen P, Bamias A, Pereira D, Wimberger P, Oaknin A, Mirza MR, Follana P, Bollag D, RayCoquard I (2014) Bevacizumab combined with chemotherapy for platinum-resistant recurrent ovarian cancer: the AURELIA openlabel randomized phase III trial. J Clin Oncol 32(13):1302-1308. https://doi.org/10.1200/JCO.2013.51.4489

75. du Bois A, Kristensen G, Ray-Coquard I, Reuss A, Pignata S, Colombo N, Denison U, Vergote I, Del Campo JM, Ottevanger P, Heubner M, Minarik T, Sevin E, de Gregorio N, Bidzinski M, Pfisterer J, Malander S, Hilpert F, Mirza MR, Scambia G, Meier W, Nicoletto MO, Bjorge L, Lortholary A, Sailer MO, Merger M, Harter P (2016) Standard first-line chemotherapy with or without nintedanib for advanced ovarian cancer (AGO-OVAR 12): a randomised, double-blind, placebo-controlled phase 3 trial. Lancet Oncol 17(1):78-89. https://doi.org/10.1016/S1470 -2045(15)00366-6

76. Ledermann JA, Embleton AC, Raja F, Perren TJ, Jayson GC, Rustin GJS, Kaye SB, Hirte H, Eisenhauer E, Vaughan M, Friedlander M, Gonzalez-Martin A, Stark D, Clark E, Farrelly L, Swart AM, Cook A, Kaplan RS, Parmar MKB (2016) Cediranib in patients with relapsed platinum-sensitive ovarian cancer (ICON6): a randomised, double-blind, placebo-controlled phase 3 trial. Lancet 387(10023):1066-1074. https://doi.org/10.1016/ S0140-6736(15)01167-8

77. Monk BJ, Poveda A, Vergote I, Raspagliesi F, Fujiwara K, Bae DS, Oaknin A, Ray-Coquard I, Provencher DM, Karlan BY, Lhomme C, Richardson G, Rincon DG, Coleman RL, Herzog TJ, Marth C, Brize A, Fabbro M, Redondo A, Bamias A, Tassoudji M, Navale L, Warner DJ, Oza AM (2014) Antiangiopoietin therapy with trebananib for recurrent ovarian cancer (TRINOVA-1): a randomised, multicentre, double-blind, placebo-controlled phase 3 trial. Lancet Oncol 15(8):799-808. https://doi.org/10.1016/S1470-2045(14)70244-X

78. Monk BJ, Poveda A, Vergote I, Raspagliesi F, Fujiwara K, Bae DS, Oaknin A, Ray-Coquard I, Provencher DM, Karlan BY, Lhomme C, Richardson G, Rincon DG, Coleman RL, Marth C, Brize A, Fabbro M, Redondo A, Bamias A, Ma H, Vogl FD, Bach BA, Oza AM (2016) Final results of a phase 3 study of trebananib plus weekly paclitaxel in recurrent ovarian cancer (TRINOVA-1): Long-term survival, impact of ascites, and progression-free survival-2. Gynecol Oncol 143(1):27-34. https:// doi.org/10.1016/j.ygyno.2016.07.112

79. du Bois A, Floquet A, Kim JW, Rau J, del Campo JM, Friedlander M, Pignata S, Fujiwara K, Vergote I, Colombo N, Mirza MR, Monk BJ, Kimmig R, Ray-Coquard I, Zang R, Diaz-Padilla I, Baumann KH, Mouret-Reynier MA, Kim JH, Kurzeder C,
Lesoin A, Vasey P, Marth C, Canzler U, Scambia G, Shimada M, Calvert P, Pujade-Lauraine E, Kim BG, Herzog TJ, Mitrica I, Schade-Brittinger C, Wang Q, Crescenzo R, Harter P (2014) Incorporation of pazopanib in maintenance therapy of ovarian cancer. J Clin Oncol 32(30):3374-3382. https://doi.org/10.1200/ JCO.2014.55.7348

80. National Comprehensive Cancer Network (2019) NCCN Clinical Practice Guidelines in Oncology: Cutaneous Melanoma, version 2.2019. https://www.nccn.org/professionals/physician_gls/pdf/ cutaneous_melanoma.pdf. Accessed 9 August 2019

81. National Comprehensive Cancer Network (2019) NCCN Clinical Practice Guidelines in Oncology: Non-small cell lung cancer, version 5.2019. https://www.nccn.org/professionals/physi cian_gls/pdf/nscl.pdf. Accessed 9 August 2019

82. Disis ML, Taylor MH, Kelly K, Beck JT, Gordon M, Moore KM, Patel MR, Chaves J, Park H, Mita AC, Hamilton EP, Annunziata CM, Grote HJ, von Heydebreck A, Grewal J, Chand V, Gulley JL (2019) Efficacy and safety of avelumab for patients with recurrent or refractory ovarian cancer: phase $1 \mathrm{~b}$ results from the JAVELIN solid tumor trial. JAMA Oncol 5(3):393-401. https://doi.org/10.1001/jamaoncol.2018.6258

83. Hamanishi J, Mandai M, Ikeda T, Minami M, Kawaguchi A, Murayama T, Kanai M, Mori Y, Matsumoto S, Chikuma S, Matsumura N, Abiko K, Baba T, Yamaguchi K, Ueda A, Hosoe Y, Morita S, Yokode M, Shimizu A, Honjo T, Konishi I (2015) Safety and antitumor activity of anti-PD-1 antibody, nivolumab, in patients with platinum-resistant ovarian cancer. J Clin Oncol 33(34):4015-4022. https://doi.org/10.1200/ JCO.2015.62.3397

84. Infante JR, Braiteh F, Emens LA, Balmanoukian AS, Oaknin A, Wang Y, Liu B, Molinero L, Fasso M, O'Hear C, Gordon M (2016) Safety, clinical activity and biomarkers of atezolizumab in advanced ovarian cancer. Ann Oncol 27(Suppl 6):vi296-vi312

85. Spira AI, Hamid O, Bauer TM, Borges VF, Wasser JS, Smith DC, Clark AS, Schmidt EV, Zhao Y, Maleski JE, Gandaghar TC (2017) Efficacy/safety of epacadostat plus pembrolizumab in triple-negative breast cancer and ovarian cancer: Phase I/II ECHO-202 study. J Clin Oncol 35(Suppl 15):1103

86. Varga A, Piha-Paul S, Ott PA, Mehnert JM, Berton-Rigaud D, Morosky A, Yang P, Ruman J, Matei D (2019) Pembrolizumab in patients with programmed death ligand 1-positive advanced ovarian cancer: analysis of KEYNOTE-028. Gynecol Oncol 152(2):243-250. https://doi.org/10.1016/j.ygyno.2018.11.017

87. Matulonis UA, Shapira-Frommer R, Santin AD, Lisyanskaya AS, Pignata S, Vergote I, Raspagliesi F, Sonke GS, Birrer M, Provencher DM, Sehouli J, Colombo N, Gonzalez-Martin A, Oaknin A, Ottevanger PB, Rudaitis V, Katchar K, Wu H, Keefe S, Ruman J, Ledermann JA (2019) Antitumor activity and safety of pembrolizumab in patients with advanced recurrent ovarian cancer: results from the phase 2 KEYNOTE-100 study. Ann Oncol. https://doi.org/10.1093/annonc/mdz135

88. Disis ML, Patel MR, Pant S, Hamilton EP, Lockhart AC, Kelly K, Beck JT, Gordon MS, Weiss GJ, Taylor MH, Chaves J, Mita AC, Chin KM, von Heydebreck A, Cuillerot J-M, Gulley JL (2016) Avelumab (MSB0010718C; anti-PD-L1) in patients with recurrent/refractory ovarian cancer from the JAVELIN solid tumor phase Ib trial: safety and clinical activity. J Clin Oncol 34(Suppl 15):5533. https://doi.org/10.1200/JCO.2016.34.15_suppl.5533

89. Columbus G (2019) Phase III avelumab trial discontinued in frontline ovarian cancer. Oncology Specialty Group. https:// www.onclive.com/web-exclusives/phase-iii-avelumab-trial-disco ntinued-in-in-frontline-ovarian-cancer. Accessed 21 March 2019

90. Jiao S, Xia W, Yamaguchi H, Wei Y, Chen MK, Hsu JM, Hsu JL, Yu WH, Du Y, Lee HH, Li CW, Chou CK, Lim SO, Chang SS, Litton J, Arun B, Hortobagyi GN, Hung MC (2017) PARP inhibitor upregulates PD-L1 expression and 
enhances cancer-associated immunosuppression. Clin Cancer Res 23(14):3711-3720. https://doi.org/10.1158/1078-0432. CCR-16-3215

91. Heinzel A, Marhold M, Mayer P, Schwarz M, Tomasich E, Lukas A, Krainer M, Perco P (2019) Synthetic lethality guiding selection of drug combinations in ovarian cancer. PLoS ONE 14(1):e0210859. https://doi.org/10.1371/journal.pone.0210859

92. Liu JF, Barry WT, Birrer M, Lee JM, Buckanovich RJ, Fleming GF, Rimel B, Buss MK, Nattam S, Hurteau J, Luo W, Quy $\mathrm{P}$, Whalen C, Obermayer L, Lee H, Winer EP, Kohn EC, Ivy SP, Matulonis UA (2014) Combination cediranib and olaparib versus olaparib alone for women with recurrent platinumsensitive ovarian cancer: a randomised phase 2 study. Lancet Oncol 15(11):1207-1214. https://doi.org/10.1016/S1470 $-2045(14) 70391-2$

93. Liu JF, Barry WT, Birrer M, Lee JM, Buckanovich RJ, Fleming GF, Rimel BJ, Buss MK, Nattam SR, Hurteau J, Luo W, Curtis J, Whalen C, Kohn EC, Ivy SP, Matulonis UA (2019) Overall survival and updated progression-free survival outcomes in a randomized phase 2 study of combination cediranib and olaparib versus olaparib in relapsed platinum-sensitive ovarian cancer. Ann Oncol 30(4):551-557. https://doi.org/10.1093/annonc/ mdz018

94. Raza MR, Mortensen CE, Avall-Lundqvist E, Bjorge L, Berek JS, Herrstedt J, Holm AJ, Kirkegaard T, Maenpaa J (2017) ENGOTOV24-NSGO/AVANOVA: Niraparib versus bevacizumab-niraparib combination versus bevacizumab and niraparib as sequential therapy in women with platinum-sensitive epithelial ovarian, fallopian tube, or peritoneal cancer. J Clin Oncol 33:5607. https ://doi.org/10.1200/jco.2015.33.15_suppl.tps5607

95. Drew Y, de Jonge M, Hong SH, Park YH, Wolfer A, Brown J, Ferguson M, Gore ME, Alvarez RH, Gresty C, Angell H, Meyer K, Learoyd M, Tang M, Lanasa M, Herbolsheimer P, Domchek SM (2018) An open-label, phase II basket study of olaparib and durvalumab (MEDIOLA): results in germline BRCA-mutated (gBRCAm) platinum-sensitive relapsed (PSR) ovarian cancer (OC). Gynecol Oncol 149:246-247

96. Konstantinopoulos PA, Waggoner SE, Vidal GA, Mita MM, Fleming GF, Holloway RW, Van Le L, Sachdev JC, ChapmanDavis E, Colon-Otero G, Penson RT, Matulonis UA, Kim YB, Moore KN, Swisher EM, Dezube BJ, Wang JY, Buerstatte N, Arora S, Munster PN (2018) TOPACIO/Keynote-162 (NCT02657889): a phase 1/2 study of niraparib + pembrolizumab in patients (pts) with advanced triple-negative breast cancer or recurrent ovarian cancer (ROC) - Results from ROC cohort. Paper presented at the Annual Meeting of the American Society of Clinical Oncology, Chicago, IL, USA, June 1-5

97. Hodi FS, Lawrence D, Lezcano C, Wu X, Zhou J, Sasada T, Zeng W, Giobbie-Hurder A, Atkins MB, Ibrahim N, Friedlander P, Flaherty KT, Murphy GF, Rodig S, Velazquez EF, Mihm MC Jr, Russell S, DiPiro PJ, Yap JT, Ramaiya N, Van den Abbeele AD, Gargano M, McDermott D (2014) Bevacizumab plus ipilimumab in patients with metastatic melanoma. Cancer Immunol Res 2(7):632-642. https://doi.org/10.1158/2326-6066.CIR-14-0053

98. Amin A, Plimack ER, Ernstoff MS, Lewis LD, Bauer TM, McDermott DF, Carducci M, Kollmannsberger C, Rini BI, Heng DYC, Knox J, Voss MH, Spratlin J, Berghorn E, Yang L, Hammers HJ (2018) Safety and efficacy of nivolumab in combination with sunitinib or pazopanib in advanced or metastatic renal cell carcinoma: the CheckMate 016 study. J Immunother Cancer 6(1):109. https://doi.org/10.1186/s40425-018-0420-0

99. Arkenau HT, Martin-Liberal J, Calvo E, Penel N, Krebs MG, Herbst RS, Walgren RA, Widau RC, Mi G, Jin J, Ferry D, Chau
I (2018) Ramucirumab plus pembrolizumab in patients with previously treated advanced or metastatic biliary tract cancer: nonrandomized, open-label, phase I trial (JVDF). Oncologist 23(12):1407-e1136. https://doi.org/10.1634/theoncolog ist.2018-0044

100. Gettinger S, Hellmann MD, Chow LQM, Borghaei H, Antonia S, Brahmer JR, Goldman JW, Gerber DE, Juergens RA, Shepherd FA, Laurie SA, Young TC, Li X, Geese WJ, Rizvi N (2018) Nivolumab plus erlotinib in patients with EGFR-mutant advanced NSCLC. J Thorac Oncol 13(9):1363-1372. https://doi. org/10.1016/j.jtho.2018.05.015

101. Yang JC, Gadgeel SM, Sequist LVD, Wu CL, Papadimitrakopoulou VA, Su WC, Fiore J, Saraf S, Raftopoulos H, Patnaik A (2019) Pembrolizumab in combination with erlotinib or gefitinib as first-line therapy for advanced non-small-cell lung cancer with sensitizing EGFR mutation. J Thorac Oncol 14(3):553-559. https ://doi.org/10.1016/j.jtho.2018.11.028

102. Carter T, Shaw H, Cohn-Brown D, Chester K, Mulholland P (2016) Ipilimumab and bevacizumab in glioblastoma. Clin Oncol (R Coll Radiol) 28(10):622-626. https://doi.org/10.1016/j. clon.2016.04.042

103. Chen SC, Chao Y, Yang MH (2017) Complete response to the combination of pembrolizumab and sorafenib for metastatic hepatocellular carcinoma: a case report. Am J Gastroenterol 112(4):659-660. https://doi.org/10.1038/ajg.2017.1

104. Li A, Sun S, Song T, Li X, Cheng W, Yao R, Zhang D, Cai Z, Zhang J, Zhai D, Yu C (2018) Targeted therapy and immunotherapy for platinum-refractory advanced ovarian adenosquamous carcinoma: a case report. Onco Targets Ther 11:3705-3711. https ://doi.org/10.2147/OTT.S162985

105. Lee JM, Cimino-Mathews A, Peer CJ, Zimmer A, Lipkowitz S, Annunziata CM, Cao L, Harrell MI, Swisher EM, Houston N, Botesteanu DA, Taube JM, Thompson E, Ogurtsova A, Xu H, Nguyen J, Ho TW, Figg WD, Kohn EC (2017) Safety and clinical activity of the programmed death-ligand 1 inhibitor durvalumab in combination with poly (ADP-ribose) polymerase inhibitor olaparib or vascular endothelial growth factor receptor 1-3 inhibitor cediranib in women's cancers: a dose-escalation, phase I study. J Clin Oncol 35(19):2193-2202. https://doi.org/10.1200/ JCO.2016.72.1340

106. Liu JF, Herold C, Luo W, Penson R, Horowitz P, Konstantinopoulos P, Castro C, Curtis J, Matulonis UA, Cannistra S, Dizon DS (2018) A phase 2 trial of the combination of nivolumab and bevacizumab in recurrent ovarian cancer. Paper presented at the Annual Meeting of the European Society of Medical Oncology, Munich, Germany, October 19-23

107. Zsiros E, Frederick PJ, Akers SN, Attwood K, Wang K, Lele SB, Odunsi K (2019) A phase II trial of pembrolizumab in combination with bevacizumab and oral metronomic cyclophosphamide for recurrent epithelial ovarian, fallopian tube or primary peritoneal cancer Paper presented at the Society of Gynecologic Oncology, Honolulu, HI, March 16-19

108. Ma Y, Kepp O, Ghiringhelli F, Apetoh L, Aymeric L, Locher C, Tesniere A, Martins I, Ly A, Haynes NM, Smyth MJ, Kroemer G, Zitvogel L (2010) Chemotherapy and radiotherapy: cryptic anticancer vaccines. Semin Immunol 22(3):113-124. https://doi. org/10.1016/j.smim.2010.03.001

Publisher's Note Springer Nature remains neutral with regard to jurisdictional claims in published maps and institutional affiliations. 